\title{
Diagnostisk suksess med fallgruver
}

Med dypsekvenseringsteknologi kan et menneskes genom sekvenseres i løpet av få dager. Diagnostiske tester basert på denne teknologien tilbys nå til omtrent samme priser som det koster å sekvensere et enkelt gen med tradisjonell metode. I Norge er også dypsekvensering diagnostisk rutine ved stadig flere laboratorier. I denne utgaven av Tidsskriftet presenterer en forskergruppe knyttet til Sykehuset i Telemark to artikler som tydelig viser hvor effektiv teknologien er i diagnostikk av sjeldne arvelige tilstander $(1,2)$. Slike tilstander, som skyldes alvorlige feil i enkeltgener, er utfordrende å diagnostisere fordi det ofte er mange gener som kan gi samme fenotype og fordi det er stor overlapp når det gjelder kliniske symptomer og funn. Rundt $30 \%$ av de undersøkte i studiene fikk påvist kausale genfeil. Dette er en imponerende høy funnprosent, på nivå med tidligere rapporter $(3,4)$. Den kliniske nytteverdien av dypsekvensering i rutinediagnostikk for denne sykdomsgruppen er godt dokumentert $(3,5,6)$, og det er ingen tvil om at denne teknologien blir et nytt hovedverktøy innenfor genetisk diagnostikk.

De to artiklene omhandler to ulike måter å bruke dypsekvenseringsteknologi på og illustrerer dermed fordeler og ulemper ved disse. I artikkelen til Høyer og medarbeidere (1) har man brukt et genpanel til å diagnostisere arvelig perifer nevropati. Forfatterne har valgt ut og sekvensert 52 relevante gener, resten av genomet ble ikke undersøkt. Testen har en teknisk nøyaktighet på 99\%, dvs. tilnærmet lik dagens gullstandard - Sanger-sekvensering (99,999\%) (7). Holla og medarbeidere har derimot brukt eksomsekvensering til diagnostikk av sjeldne syndromer og utviklingshemning (2). Ved denne metoden sekvenseres alle eksonene, dvs. de kodende regionene for våre ca. 20000 proteinkodende gener (5). Denne teknikken har ikke tilsvarende teknisk nøyaktighet fordi ikke alle eksonene er sekvensert så mange ganger (dypt) som ønskelig, det er variabel dekningsgrad. Årsaken til at det likevel er fornuftig å bruke denne metoden i diagnostikk, er at enkelte arvelige tilstander kan skyldes genfeil i ett av svært mange gener (> 500 ved utviklingshemning), samtidig som det kontinuerlig identifiseres nye sykdomsgener (5). Kun vel halvparten av alle de rundt 8000 sjeldne arvelige sykdommene som er beskrevet har kjent genetisk årsak (8). Et bestemt genpanel for en gitt tilstand vil dermed raskt bli utdatert (1). Å legge til nye gener i en spesifikk paneltest er arbeidskrevende.

Det har vært knyttet stor bekymring til at man ved eksomsekvensering også kan påvise genvarianter som gir risiko for annen type sykdom enn den som er relatert til problemstillingen (9). I klinisk praksis opplever vi imidlertid dette som et lite problem. Hos de 125 pasientene som fikk utført eksomsekvensering i Høyers studie, ble det ikke påvist noen tilfeldige risikovarianter. I litteraturen rapporteres fra $<1 \%$ til $8 \%$ tilfeldige funn $(4,5)$. Tilfeldige funn er ikke noe nytt i medisinsk diagnostikk. Det viktige er at pasientene veiledes om dette på forhånd og at de samtykker til hvilken risikoinformasjon de ønsker tilbakemelding om. Det er også viktig at pasienten er klar over at de som analyserer genomdata ikke har plikt til å lete etter slike tilfeldige risikovarianter. Eksom- og genomsekvensering er de viktigste redskapene for persontilpasset medisin, dvs. «skreddersydd» diagnostikk og behandling. Helsedirektoratet utarbeider nå en strategi for innføring av persontilpasset medisin $i$ helsevesenet. For at satsingen skal lykkes, er det avgjørende at vi henter ut den informasjonen vi trenger fra genomet på en målrettet måte. En forventning, eller et krav, om at man ved eksomsekvensering skal kunne få tilbakemelding om alle mulige varianter som kan ha betydning for fremtidig sykdom, vil gjøre diagnostikken meget lite effektiv.

Det er generelt svært krevende å tolke genvarianters betydning for sykdom. Vi har alle sjeldne normalvarianter som ingen har beskrevet før, og for hver patogene variant vi rapporterer i et gitt gen, rapporteres minst dobbelt så mange varianter med usikker betydning. Feiltolkninger vil ha konsekvenser for liv og helse for pasientene, og dette forekommer allerede, fordi rekvirentene ikke forstår laboratoriesvaret. God kommunikasjon mellom laboratorium og rekvirenter er av avgjørende betydning, og man bør i fellesskap utarbeide rutiner for hvem som kan rekvirere disse nye testene, samt for hvilke indikasjoner. En handlingsplan for etterutdanning i medisinsk genetikk av alle landets leger bør på plass så snart som mulig. Dersom man ikke tar dette alvorlig, vil prisen bli høy i form av feildiagnostikk, feilbehandling og feil bruk av ressurser. Med stadig flere dyre tester og behandlinger på markedet, tvinger det seg også frem et behov for klare retningslinjer for prioritering.

Innenfor det medisinsk genetiske fagfeltet har vi nå store forventninger til den nasjonale strategien for persontilpasset medisin som er under utarbeiding. Det er mange utfordringer som må møtes dersom dypsekvenseringsteknologi skal bli brukt til beste for pasientene: Håndtering av usikre varianter og tilfeldige risikovarianter, aktiv prioritering, økonomisk tilrettelegging og ikke minst videreutdanning av helsepersonell - alt dette er nøkkelfaktorer som kan bestemme suksess eller fiasko for persontilpasset medisin i nær fremtid.

\section{Torunn Fiskerstrand}

Torunn.fiskerstrand@helse-bergen.no

Torunn Fiskerstrand (f. 1965) er dr.philos., overlege og førsteamanuensis ved Senter for medisinsk genetikk og molekylærmedisin ved Haukeland universitetssykehus. Hun er leder av Norsk forening for medisinsk genetikk.

Forfatter har fylt ut ICMJE-skjemaet og oppgir ingen interessekonflikter.

\section{Litteratur}

1. Høyer $H$, Busk $\emptyset \mathrm{L}$, Holla $\emptyset \mathrm{L}$ et al. Arvelige perifere nevropatier diagnostisert ved dypsekvensering. Tidsskr Nor Legeforen 2015; 135: 1838-43.

2. Holla $\emptyset \mathrm{L}$, Busk $\emptyset \mathrm{L}$, Tveten $\mathrm{K}$ et al. Diagnostisk eksomsekvensering - norske erfaringer. Tidsskr Nor Legeforen 2015; 135: 1833-7.

3. Sawyer SL, Hartley T, Dyment DA et al. Utility of whole-exome sequencing for those near the end of the diagnostic odyssey: time to address gaps in care. Clin Genet 2015; e-publisert 18.8.2015.

4. Yang Y, Muzny DM, Xia F et al. Molecular findings among patients referred for clinical whole-exome sequencing. JAMA 2014; 312: 1870-9

5. Xue Y, Ankala A, Wilcox WR et al. Solving the molecular diagnostic testing conundrum for Mendelian disorders in the era of next-generation sequencing: single-gene, gene panel, or exome/genome sequencing. Genet Med 2015; 17: 444-51.

6. Valencia CA, Husami A, Holle J et al. Clinical Impact and Cost-Effectiveness of Whole Exome Sequencing as a Diagnostic Tool: A Pediatric Center's Experience. Front Pediatr 2015; 3: 67

7. Shendure J, Ji H. Next-generation DNA sequencing. Nat Biotechnol 2008; 26 $1135-45$.

8. Online Mendelian Inheritance in Man. www.omim.org (16.10.2015)

Burke W. Antommaria AH, Bennett $\mathrm{R}$ et al. Recommendations for returning genomic incidental findings? We need to talk! Genet Med 2013; 15: 854-9. 